\title{
PENGARUH LIKUIDITAS, PROFITABILITAS DAN LEVERAGE TERHADAP KEBIJAKAN DIVIDEN PADA PERUSAHAAN MANUFAKTUR DI BURSA EFEK INDONESIA
}

\author{
Ni Gusti Ayu Putu Debi Monika ${ }^{1}$ \\ Luh Komang Sudjarni ${ }^{2}$ \\ ${ }^{1,2}$ Fakultas Ekonomi dan Bisnis Universitas Udayana, Bali, Indonesia \\ email: monika_debi@yahoo.com
}

\begin{abstract}
ABSTRAK
Kebijakan dividen menyangkut tentang masalah penggunaan laba yang menjadi hak para pemegang saham, laba tersebut bisa dibagi sebagai dividen atau ditahan untuk diinvestasikan kembali.Penelitian ini bertujuan untuk mengetahui pengaruh likuiditas, profitabilitas, dan leverage terhadap kebijakan dividen pada perusahaan manufaktur yang terdaftar di Bursa Efek Indonesia periode 2011-2015.Populasi dalam penelitian ini adalah perusahaan manufaktur yang berjumlah 144 perusahaan.Teknik pengambilan sampel yang digunakan adalah purposive sampling sehingga didapat sebanyak 15 sampel perusahaan pada perusahaan manufaktur.Metode pengumpulan data yang digunakan dalam penelitian adalah observasi non partisipan, dengan data berupa laporan keuangan yang diperoleh dari www.idx.co.id.Teknik analisis data yang digunakan adalah regresi linear berganda. Berdasarkan hasil analisis menunjukkan bahwa secara parsial likuiditas dan profitabiltas berpengaruh positif signifikan terhadap kebijakan dividen dan leverage berpengaruh negatif signifikan terhadap kebijakan dividen pada perusahaan manufaktur di Bursa Efek Indonesia periode 2011-2015.
\end{abstract}

Kata kunci: likuiditas, profitabiltas, leverage, kebijakan dividen.

\begin{abstract}
The dividend policy concerns the issue of the use of profits which are the rights of shareholders, the profits may be divided as dividends or retained for reinvestment. This study aims to determine the effect of liquidity, profitability, and leverage on dividend policy on manufacturing companies listed on the Indonesia Stock Exchange period 2011-2015. The population in this study is a manufacturing company which amounted to 144 companies. The sampling technique used is purposive sampling so as to get as many as 15 sample company at manufacturing company. Data collection method used in the research is non participant observation, with data in the form of financial statements obtained from www.idx.co.id. The data analysis technique used is multiple linear regression. Based on the results of the analysis show that partially liquidity and profitability significantly positive effect on dividend and leverage policies have a significant negative effect on dividend policy on manufacturing companies in Indonesia Stock Exchange period 2011-2015.
\end{abstract}

Keywords: liquidity, profitability, leverage, dividend policy 
Ni Gusti Ayu Putu Debi Monika, Pengaruh Likuiditas, ...

\section{PENDAHULUAN}

Perusahaan yang didirikan tentu mempunyai tujuan utama, yaitu mencapai laba maksimal. Laba yang diperoleh perusahaan inilah akan digunakan untuk menjalankan kegiatan operasi perusahaan. Sumber dana dikelola oleh perusahaan agar kegiatan operasinya berjalan dengan lancar. Pengaturan kegiatan keuangan perusahaan dinamakan manajemen keuangan. Kegiatan yang ada pada manajemen keuangan terdiri dari perencanaan keuangan, analisis keuangan dan pengendalian keuangan. Orang-orang yang melaksanakan kegiatan tersebut dinamakan manajer keuangan (Husnan dan Pudjiastuti, 2006:4). Kegiatan keuangan yang dilakukan oleh manajer keuangan dibagi menjadi dua kegiatan utama, yaitu mendapatkan dana dan mengalokasikan dana tersebut dalam berbagai macam bentuk pembiayaan investasi dan pembelanjaan secara efisien. Dua kegiatan utama tersebut, terdapat fungsi-fungsi keuangan yakni, keputusan investasi, keputusan pendanaan dan kebijakan dividen (Wiagustini, 2010:5). Fungsi keuangan tersebut bertujuan untuk meningkatkan kemakmuran pemilik perusahaan.

Kebijakan dividen adalah bagian yang tidak terpisahkan dalam keputusan pendanaan perusahaan (Horne dan Wachowicz, 2012:206). Kebijakan dividen merupakan keputusan setelah perusahaan beroperasi dan memperoleh laba. Informasi yang terdapat didalam pengumuman pembagian dividen sebuah perusahaan akan memberikan sinyal bagi investor mengenai perubahan harga saham. Perusahaan yang membagikan dividen dianggap telah berkinerja dengan baik dan memperoleh keuntungan sehingga akan lebih menarik minat investor yang nantinya akan meningkatkan permintaan terhadap saham perusahaan. 
Pembayaran dividen yang stabil dapat menandakan bahwa perusahaan tersebut pada kondisi yang sehat dan menunjukkan pihak manajemen perusahaan berkinerja dengan baik. Cara yang dapat dilakukan oleh investor untuk menilai kinerja perusahaan diantaranya adalah mengevaluasi laporan keuangannya menggunakan analisis rasio keuangan. Rasio keuangan dapat membantu investor untuk mengevaluasi laporan keuangan perusahaan (Brigham dan Houston, 2011:133).

Keuntungan yang diperoleh perusahaan jika digunakan untuk memenuhi keinginan investor terhadap dividen yang tinggi, maka keputusan menahan laba untuk kepentingan perusahaan akan terabaikan, sebaliknya jika perusahaan menahan laba maka kepentingan pemegang saham terhadap keuntungan dividen juga terabaikan. Berkaitan dengan hal itu diperlukan kebijakan dividen untuk mengatur besar kecilnya dividen yang dibagikan. Gumanti (2013:6) mengatakan bahwa, keputusan yang diambil oleh manajemen harus mengutamakan upaya untuk memaksimalkan kemakmuran pemegang saham, maka dari itu sebagai pemilik perusahaan dan manajer adalah individu yang ditugaskan untuk mengelola perusahaan. Manajer keuangan harus mengambil keputusan kebijakan dividen yang optimal untuk menjaga kedua kepentingan yang berlawanan tersebut.Horne dan Wachowicz (2012:270) menyatakan bahwa jumlah dan jenis dividen yang dibagikan pun harus berdasarkan kebijakan pemimpin Rapat Umum Pemegang Saham (RUPS).

Sudana (2011:167) mengatakan bahwa, kebijakan dividen berhubungan dengan penentuan besarnya dividend payout ratio (DPR), yaitu besarnya 
Ni Gusti Ayu Putu Debi Monika, Pengaruh Likuiditas, ...

persentase laba bersih setelah pajak yang dibagikan sebagai dividen kepada pemegang saham. Besar kecilnya dividen yang akan dibagikan sangat tergantung pada besar kecilnya laba yang diperoleh. Kebijakan dividen menyangkut masalah penggunaan profit yang menjadi hak para pemegang saham, profit tersebut bisa dibagi sebagai dividen atau ditahan untuk diputar kembali (Husnan, 2012:157). Kebijakan dividen dalam penelitian ini diukur menggunakan dividend payout ratio (DPR) sebagai variabel dependen. Brigham dan Houston (2011:211) menyatakan bahwa dividend payout ratio adalah persentase dari laba bersih yang akan dibayarkan sebagai dividen tunai kepada pemegang saham.

Faktor-faktor yang mempengaruhi kebijakan dividen menurut Keown, et al. (2010:227) yaitu: posisi likuiditas perusahaan, aksebilitas ke pasar modal, tingkat inflasi, pembatasan legal, stabilitas pendapatan, keinginan investor untuk mempertahankan kontrol atas perusahaan. Hanafi (2008:375) menyatakan bahwa, faktor-faktor yang mempengaruhi kebijakan dividen yaitu: profitabilitas, kesempatan investasi, likuiditas, akses ke pasar keuangan, stabilitas pendapatan, pembatasan-pembatasan yang diberikan kreditur. Wiagustini (2010:257) menyatakan bahwa, faktor-faktor yang mempengaruhi kebijakan dividen antara lain: likuiditas, kebutuhan pembayaran kembali utang perusahaan, tingkat ekspansi yang tinggi, akses perusahaan di pasar modal, posisi pemegang saham dalam kelompok pajak. Penelitian terdahulu telah menguji apakah faktor-faktor, seperti likuiditas, profitabilitas, dan leverage mempengaruhi kebijakan dividen dan masih terdapat research gap dari penelitian sebelumnya. 
Likuiditas adalah rasio yang menggambarkan kemampuan perusahaan membayar (utang) jangka pendek. Perusahaan yang mempunyai tingkat likuiditas tinggi secara tidak langsung akan memberikan gambaran bahwa perusahaan mampu memenuhi kewajiban-kewajiban jangka pendeknya. Likuiditas perusahaan ditunjukkan oleh besar kecilnya aktiva lancar yaitu aktiva yang mudah untuk diubah menjadi kas yang meliputi kas, surat berharga, piutang dan persediaan (Sartono, 2010:116). Alat ukur yang biasa digunakan untuk menghitung tingkat likuiditas adalah current ratio, quick ratio, cash ratio, net working capital to sales, current asset to sales (Wiagustini, 2010:78). Penelitian ini menggunakan cash ratio yaitu kas dibandingkan dengan utang lancar sebagai alat ukur karena kas merupakan aktiva lancar yang paling likuid.

Sartono (2010:293) mengatakan bahwa, pengaruh likuiditas searah dengan kebijakan dividen yang dimana semakin besar likuiditas pada suatu perusahaan maka semakin besar pula kemampuan perusahaan dalam membayarkan dividennya. Penelitian yang dilakukan oleh Dewi dan Panji (2012), Wicaksana (2012), Mehta (2012), Sartika Sari (2014) serta Adnyana (2014) yang menyatakan bahwa likuiditas berpengaruh positif dan signifikan terhadap kebijakan dividen. Semakin likuid sebuah perusahaan, kemungkinan pembayaran dividen yang dilakukan perusahaan tersebut akan semakin besar. Hasil yang berbeda diungkapkan oleh Griffin (2010), Suprasanda (2011), Imran (2011), Novatiani dan Oktaviani (2012) menyatakan bahwa, likuiditas berpengaruh negatif terhadap kebijakan dividen. Semakin tinggi likuiditas maka semakin rendah dividen yang dibagikan karena ada laba ditahan untuk kepentingan investasi. 
Ni Gusti Ayu Putu Debi Monika, Pengaruh Likuiditas, ...

Profitabilitas merupakan salah satu rasio yang digunakan untuk menganalisis keuangan yang bertujuan untuk mengetahui kemampuan perusahaan untuk memperoleh laba atau ukuran keefektifan perusahaan dalam mengelola perusahaannya (Wiagustini, 2010:76). Rasio profitabilitas dapat dilakukan dengan cara menggunakan perbandingan antara komponen yang ada di laporan keuangan, terutama pada laporan keuangan neraca dan laba rugi. Pengukuran dapat dilakukan untuk beberapa periode operasi. Tujuannya adalah agar terlihat perkembangan perusahaan dalam rentang waktu tertentu, baik penurunan atau kenaikan, sekaligus mencari penyebab perubahan tersebut (Kasmir, 2011:196). Investor jangka panjang sangat berkepentingan dengan analisis profitabilitas, misalnya pemegang saham akan melihat keuntungan yang benar-benar diterima dalam bentuk dividen (Sartono, 2010:122). Wiagustini (2010:81) menyatakan bahwa, alat ukur yang digunakan untuk mengukur profitabilitas adalah profit margin, return on investment, dan return on equity. Penelitian ini akan menggunakan ROE yaitu laba bersih dibagi dengan ekuitas sebagai alat ukur karena sangat berkaitan dengan saham yang dimiliki investor.

Penelitian yang dilakukan Juhandi, et al. (2013), Nursalam (2013), Estiaji (2014), Thanatawee (2013), Dinata dan Yadnya (2014) menyatakan bahwa variabel profitabilitas berpengaruh positif dan signifikan terhadap kebijakan dividen. Perusahaan dengan tingkat profitabilitas yang tinggi maka, semakin besar pula kemampuan perusahaan membayar dividen.Penelitian yang berbeda dilakukan oleh Sulistiyowati (2012), Islam et al (2012).Lopolusi (2013), Maladjian dan Khoury (2014) dan Rahayuningtyas (2014) menyatakan bahwa, 
profitabilitas yang diukur dengan return on equity (ROE) berpengaruh negatif terhadap kebijakan dividen. Artinya laba perusahaan yang tinggi digunakan untuk berinvestasi sehingga dividen yang dibayarkan kecil.

Leverage adalah rasio untuk mengukur sampai seberapa jauh perusahaan dibiayai oleh dana pinjaman (Wiagustini, 2010:77). Penggunaan utang dalam jumlah yang besar akan meningkatkan risiko perusahaan, yang meningkatkan biaya dari utang (Brigham dan Houston, 2011:153). Utang perusahaan tinggi maka investor tidak akan tertarik untuk membeli saham perusahaan karena tidak sesuai dengan harapan investor yaitu bagian dividen. Leverage tinggi maka dividen dibayarkan rendah, berarti ada pengaruh negatif antara leverage terhadap dividen. Alat ukur yang digunakan untuk mengukur leverage adalah debt to asset ratio, debt to equity ratio, long term debt to equity, times interest earned, fixed charge coverage (Kasmir, 2012:156). Rasio leverage dalam penelitian ini diproksikan dengan debt to equity ratio (DER) yaitu rasio yang megukur persentase dana yang diberikan oleh kreditur dengan cara membagi total utang perusahaan terhadap total ekuitas (Brigham and Houston, 2011:143). Debt to equity ratio (DER) merupakan analisis yang melihat apakah perusahaan mampu membayar seluruh kewajiban jangka panjang dan jangka pendeknya. Apabila semakin besar rasio DER menunjukkan semakin besar pula kewajibannya dan rasio yang semakin rendah artinya dalam memenuhi pendanaan harus lebih banyak menggunakan modal sendiri.

Penelitian yang dilakukan oleh John (2010), Jannati (2012), Sunarya (2013), Rachmad dan Muid (2013), Lopolusi (2013) dan Huda dan Abdullah (2013) yang 
Ni Gusti Ayu Putu Debi Monika, Pengaruh Likuiditas, ...

menyatakan bahwa leverage berpengaruh negatif terhadap kebijakan dividen. Pengaruh negatif artinya semakin tinggi utang maka perusahaan membayar bunga juga tinggi sehingga akan menurunkan laba. Turunnya laba perusahaan berarti menurunkan pembagian dividen.Penelitian berbeda menurut Sulistiyowati (2012), Elissya (2013),Deitiana (2013),dan Rahayuningtyas (2014) menyatakan bahwa leverage berpengaruh positif terhadap kebijakan dividen. Pengaruh positif artinya jika perusahaan memiliki utang yang sedikit dimana bunga dibayarkan rendah dan laba perusahaan tinggi tetapi laba tersebut sebagian ditahan perusahaan maka dividen dibayarkan rendah. Laba yang ditahan saat ini dalam jumlah yang lebih besar dalam perusahaan berarti lebih sedikit uang yang akan tersedia bagi pembayaran dividen (Horne dan Wachowicz, 2012:270).

Penelitian ini menggunakan perusahaan dari sektor manufaktur dalam objek penelitian. Perusahaan manufaktur adalah sektor perusahaan terbesar yang terdaftar pada Bursa Efek Indonesia dibandingkan perusahaan lain. Pengambilan sampel pada sektor manufaktur dapat lebih luas dan tidak hanya mencakup dari satu sektor saja tetapi dari semua sektor yang ada. Periode penelitian selama 5 tahun yaitu dari tahun 2011 sampai dengan tahun 2015. Penelitian 5 tahun dengan asumsi semakin besar jumlah sampel yang diamati dan semakin panjang periode penelitian tersebut, maka hasil penelitian yang diharapkan semakin akurat. 
Tabel 1.

Tingkat Rata-rata Likuiditas (Cash Ratio), Profitabilitas (ROE),Leverage (DER) dan Dividend Payout Ratio (DPR) Perusahaan Manufaktur di Bursa Efek Indonesia (BEI) Periode 2011-2015

\begin{tabular}{llllll}
\hline \multicolumn{1}{c}{ Variabel } & & \multicolumn{5}{c}{ Tahun } \\
\hline $\begin{array}{l}\text { Cash Ratio } \\
\text { (dalam \%) }\end{array}$ & $\mathbf{2 0 1 1}$ & $\mathbf{2 0 1 2}$ & $\mathbf{2 0 1 3}$ & $\mathbf{2 0 1 4}$ & $\mathbf{2 0 1 5}$ \\
$\begin{array}{l}\text { ROE (dalam } \\
\text { \%) }\end{array}$ & 36,94 & 53,65 & 59,62 & 53,57 & 47,52 \\
$\begin{array}{l}\text { DER (dalam } \\
\text { \%) }\end{array}$ & 54,66 & 29,05 & 29,70 & 28,57 & 25,48 \\
$\begin{array}{l}\text { DPR (dalam } \\
\text { \%) }\end{array}$ & 50,55 & 56,76 & 61,82 & 68,51 & 59,77 \\
\hline
\end{tabular}

Sumber : Lampiran 4,5,6 dan 7.

Berdasarkan Tabel 1 dapat dilakukan analisis sementara pengaruh variabelvariabel bebas terhadap dividend payout ratio (DPR).Analisis sementara tersebut untuk mengetahui konsistensi pengaruh likuiditas (cash ratio), profitabilitas (ROE), dan leverage (DER) yang diperkirakan berpengaruh positif terhadap DPR.

Tahun 2013 likuiditas yang diproksikan menggunakan cash ratio mengalami peningkatan dari tahun sebelumnya sebesar 5,97\%, akan tetapi DPR tahun 2013 mengalami penurunan dari tahun sebelumnya sebesar 9,95\%. Hal ini tidak sesuai dengan pernyataan Wiagustini (2011:257), bahwa posisi likuiditas mempengaruhi tingkat pembayaran dividen.

Pada variabel profitabilitas yang diproksikan menggunakan ROE terjadi fenomena pada tahun 2013 mengalami peningkatan dari tahun sebelumnya sebesar 0,65\%, akan tetapi DPR tahun 2013 mengalami penurunan dari tahun sebelumnya sebesar 9,95\%. Fenomena ini tidak sesuai pada apa yang dikemukakan oleh Lintner (1956), bahwa kemampuan perusahaan dalam 
mendapatkan laba adalah tujuan utama dalam penentuan tingkat pembayaran dividen perusahaan kepada pemegang saham.

Variabel leverage yang diproksikan menggunakan DER terjadi fenomena pada tahun 2012 mengalami peningkatan dari tahun sebelumnya sebesar 6,1\%, peningkatan DER disertai dengan meningkatnya DPR tahun 2012 sebesar 6,18\%. Tahun 2013 DER meningkat sebesar 1,06\%, akan tetapi DPR tahun 2013 mengalami penurunan dari tahun sebelumnya sebesar 9,95\%. Fenomena ini bertentangan dengan teori yang menyatakan bahwa kemampuan meminjam yang lebih besar, fleksibilitas yang lebih besar akan memperbesar kemampuan membayar dividen (Sartono, 2010:293).

Rasio likuiditas merupakan rasio yang menunjukkan kemampuan perusahaan untuk memenuhi kewajiban (utang) dalam jangka pendek dengan dana lancar yang tersedia (Wiagustini, 2010:76). Dividen bagi perusahaan merupakan kas keluar, maka semakin besar posisi kas dan likuiditas perusahaan akan semakin besar kemampuan perusahaan untuk membayar dividen (Sartono, 2010:293). Penelitian ini menggunakan cash ratio sebagai alat ukur likuiditas karena kas merupakan bagian dari aktiva lancar yang sangat likuid.Jika kas tinggi maka perusahaan sangat mampu membayar dividen.

Penelitian oleh Aljannah (2010), Kuwari (2010), Karami (2011), Rehman (2012), dan Sartika (2014) menyatakan bahwa likuiditas memiliki pengaruh yang positf dan signifikan terhadap kebijakan dividen. Semakin tinggi likuiditas pada suatu perusahaan, maka semakin tinggi pula harapan perusahaan untuk mampu membayarkan dividen kepada pemegang saham. 
$\mathrm{H}_{1}$ : Likuiditas berpengaruh positif terhadap kebijakan dividen.

Profitabilitas merupakan kemampuan perusahaan untuk menghasilkan atau memperoleh laba selama periode tertentu dengan menggunakan aktiva yang produktif atau modal, baik modal secara keseluruhan maupun modal sendiri (Munawir, 2010:33). Pembagian dividen yang sumbernya dari keuntungan yang didapatkan perusahaan setelah memenuhi kewajiban-kewajibannya baik berupa bunga maupun pajak. Apabila semakin besar keuntungan bersih yang diperoleh perusahaan maka semakin besar pula dividen yang akan dibayarkan. Pengukuran rasio profitabilitas dalam penelitian ini menggunakan ROE yang menunjukkan sejauh mana perusahaan dapat mengelola modal sendiri (ekuitas) secara efektif dan mengukur tingkat keuntungan dari investasi yang telah dilakukan pemegang saham perusahaan.

Penelitian yang dilakukan Juhandi, et al (2013), Nursalam (2013), Thanatawee (2013), Estiaji (2014), Dinata dan Yadnya (2014) menyebutkan bahwa variabel profitabilitas berpengaruh positif dan signifikan terhadap kebijakan dividen. Hal tersebut dikarenakan meningkatnya keuntungan perusahaan akan meningkatkan pula pembagian dividen kepada pemegang saham $\mathrm{H}_{2}$ : Profitabilitas berpengaruh positif terhadap kebijakan dividen.

Leverage adalah kemampuan perusahaan untuk memenuhi kewajiban (utang) baik jangka pendek maupun jangka panjang (Wiagustini, 2010:76). Apabila semakin besar tingkat utang menunjukkan bahwa semakin besar kewajiban yang harus dipenuhi oleh perusahaan, begitu pula sebaliknya semakin kecil tingkat utang itu berarti bahwa perusahaan mampu memenuhi kebutuhan 
pendanaan perusahaan dengan modal sendiri juga akan rendah. Tingginya kewajiban yang harus dibayarkan akan berkurangnya keuntungan yang didapat perusahaan, tentunya akan berdampak pada pembagian dividen. Maka dari itu, semakin tinggi utang maka semakin rendah tingkat dividen yang akan dibagikan. Penelitian ini menggunakan alat ukur leverage yaitu debt to equity ratio, merupakan rasio yang digunakan untuk menilai utang dengan ekuitas. Rasio ini dicari dengan cara membandingkan antara seluruh utang, termasuk utang lancar dengan seluruh ekuitas (Kasmir, 2012:156).

Penelitian John (2010), Attina (2011), Sunarya (2013), Rachmad dan Muid (2013), Lopolusi (2013) dan Huda dan Abdullah (2013) menyatakan bahwa leverage berpengaruh negatif terhadap kebijakan dividen. Tingkat leverage yang tinggi dapat mengakibatkan rendahnya kemampuan perusahaan membayar dividen kepada pemegang saham, karena perusahaan harus membayar kewajibankewajiban perusahaan.

$\mathrm{H}_{3}$ : Leverage berpengaruh negatif terhadap kebijakan dividen.

\section{METODE PENELITIAN}

Penelitian ini dilakukan untuk mengetahui pengaruh likuiditas, profitabilitas dan leverage terhadap kebijakan dividen pada perusahaan manufaktur di Bursa Efek Indonesia. Berdasarkan penjelasan diatas maka kerangka pemikiran teoritis dapat digambarkan model penelitian sebagai berikut: 


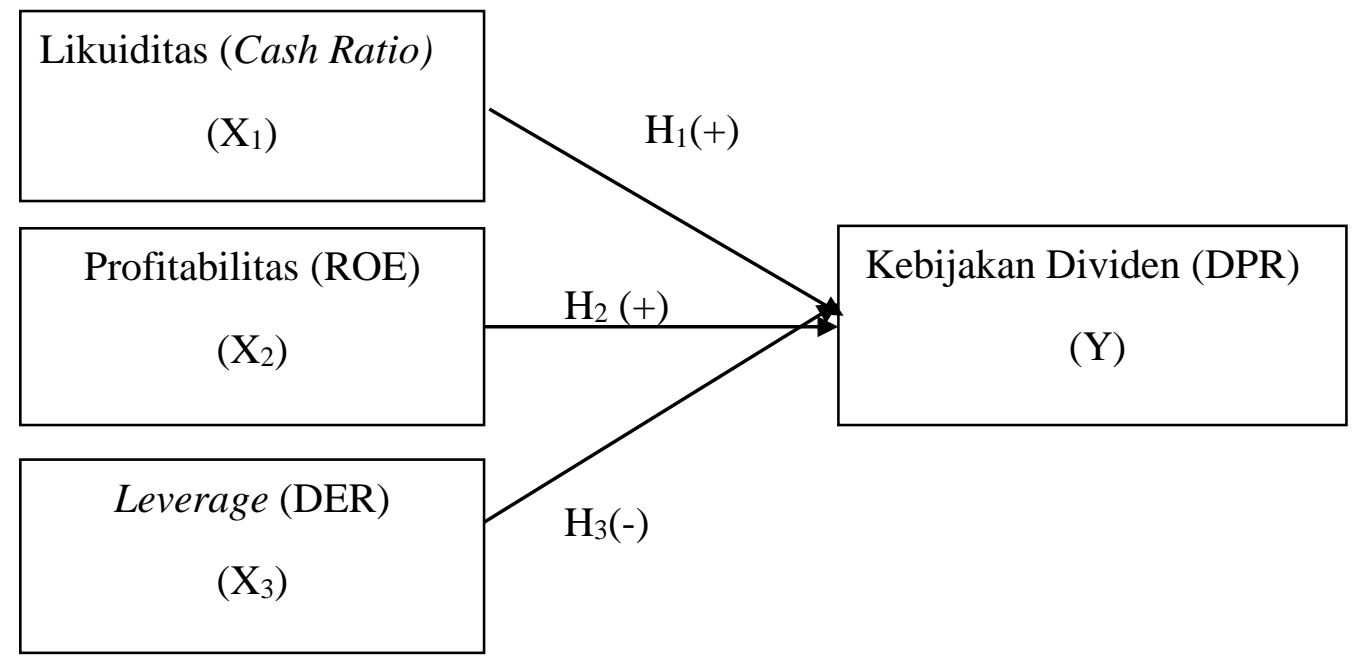

\section{Gambar 1. Model Penelitian}

Kebijakan dividen merupakan pembagian hasil laba yang diberikan perusahaan penerbit saham tersebut atas keuntungan yang dihasilkan perusahaan. Kebijakan dividen dalam penelitian ini menggunakan dividend payout ratio (DPR) yaitu persentase dividen yang dibagikan kepada pemegang saham dari laba bersih setelah pajak. Dividend payout ratio dihitung dengan cara membandingkan antara dividen yang dibagi dengan laba setelah pajak pada perusahaan manufaktur di Bursa Efek Indonesia periode 2011-2015. Satuan pengukuran dividend payout ratio adalah dalam persentase (\%). DPR dapat dihitung dengan rumus sebagai berikut:

Dividend Payout Ratio $($ DPR $)=\frac{\text { Dividen per lembar saham }}{\text { Laba per lembar saham }} \times 100 \%$

Rasio likuiditas menunjukkan kemampuan perusahaan untuk memenuhi kewajiban finansial yang berjangka pendek tepat pada waktunya. Cash Ratio adalah salah satu ukuran dari rasio likuiditas (liquidity ratio) yang merupakan kemampuan perusahaan memenuhi kewajiban jangka pendeknya (current liability) melalui sejumlah kas dan setara kas (seperti giro atau simpanan lain di 
bank yang dapat ditarik setiap saat) yang dimiliki perusahaan. Satuan pengukuran cash ratio adalah dalam persentase (\%). Cash ratio dapat dihitung dengan rumus sebagai berikut:

Cash Ratio $=\frac{\text { Kas }+ \text { Bank }}{\text { Current liabilities }} \times 100 \%$

Profitabilitas diukur dengan Return On Equity (ROE). Return On Equity (ROE) merupakan perbandingan laba bersih dengan modal sendiri perusahaan yang terdapat pada perusahaan manufaktur di Bursa Efek Indonesia (BEI) dalam periode penelitian 2011-2015. Satuan Return On Equity adalah satuan persen (\%), yang dihitung sebagai berikut:

Return On Equity $(\mathrm{ROE})=\frac{\text { Laba Bersih }}{\text { Modal Sendiri }} \times 100 \%$

Rasio leverage mendeskripsikan seberapa besar modal pinjaman yang digunakan oleh perusahaan dalam segala kegiatan operasional perusahaan. Leverage pada penelitian ini diproksikan dengan debt to equity ratio (DER) untuk mengetahui seberapa besar modal yang digunakan untuk menutupi keseluruhan utang kepada pihak luar. Leverage dapat dihitung dengan cara membandingkan antara total kewajiban atau hutang perusahaan terhadap total ekuitas atau modal sendiripada perusahaan manufaktur yang terdaftar di Bursa Efek Indonesia periode tahun 2011-2015 (dengan satuan persentase).

Debt to equity ratio $(\mathrm{DER})=\frac{\text { Total utang }}{\text { Jumlah modal sendiri }} \times 100 \%$

Jenis data yang digunakan dalam penelitian ini yaitu data kuantitatif pada penelitian ini meliputi laporan keuangan tahunanperusahaan manufaktur yang terdaftar pada Bursa Efek Indonesia periode 2011-2015.Data kualitatif dalam 
penelitian ini adalah daftar perusahaan manufaktur serta gambaran umum perusahaan manufaktur yang terdaftar di Bursa Efek Indonesia (BEI) selama periode 2011-2015.Sumber data yang digunakan dalam penelitian ini adalah data sekunder.Data sekunder yang digunakan dalam penelitian ini adalah publikasi laporan keuangan cash ratio, ROE, DER dan DPR pada perusahaan manufakturdi Bursa Efek Indonesia periode 2011-2015 melalui situs resmi www.idx.co.id.

Populasi dalam penelitian ini adalah perusahaan yang aktif diperdagangkan yaitu perusahaan manufaktur di Bursa Efek Indonesa dengan rentang waktu periode 2011-2015 yang berjumlah 144 perusahaan.Sektor manufaktur dijadikan sebagai populasi dari penelitian ini dengan pertimbangan karena perusahaan manufaktur adalah kelompok perusahaan besar yang terdaftar pada Bursa Efek Indonesia dibandingkan perusahaan lain. Pengambilan sampel dalam penelitian ini dilakukan dengan menggunakan teknik purposive sampling, yaitu pengambilan sampel dengan mempertimbangkan kiteria tertentu. Jumlah sampel yang memenuhi kriteria dalam penelitian ini adalah sejumlah 15dan times series 5, yaitu 2011-2015.

\section{HASIL DAN PEMBAHASAN}

Analisis data deskriptif dilakukan untuk memberikan gambaran atau deskripsi mengenai variabel yang diteliti dimana terdiri dari Likuiditas $\left(\mathrm{X}_{1}\right)$, Profitabilitas $\left(\mathrm{X}_{2}\right)$, Leverage $\left(\mathrm{X}_{3}\right)$ dan DPR (Y). Uji statistik deskriptif mencangkup nilai rata-rata (mean), nilai minimum, nilai maksimum, dan standar deviasi dari data penelitian. Untuk memperjelas dan mempermudah pemahaman atas hasil penelitian ini, akan dideskripsikan hasil dari masing-masing faktor yang 
menjadi variabel dalam penelitian ini. Hasil statistik deskriptif disajikan pada tabel 2 berikut ini.

Tabel 2.

Hasil Statistik Deskriptif

\begin{tabular}{lrrrrr}
\hline & N & Minimum & Maximum & Mean & $\begin{array}{c}\text { Std. } \\
\text { Deviation }\end{array}$ \\
\hline Likuiditas & 75 & 15.34 & 98.31 & 54.2635 & 20.96822 \\
Profitabilitas & 75 & 10.12 & 95.81 & 29.3757 & 21.83211 \\
Leverage & 75 & 15.80 & 98.45 & 61.1085 & 26.44745 \\
DPR & 75 & 14.03 & 99.89 & 50.8147 & 23.02973 \\
Valid N & 75 & & & & \\
(listwise) & & & & & \\
\hline \multicolumn{1}{c}{ Sumber: Data Diolah, 2017. } & & & &
\end{tabular}

Berdasarkan hasil uji statistik deskriptif pada tabel 2 dapat dijelaskan bahwa jumlah data yang digunakan dalam penelitian ini berjumlah 75.Tabel tersebut menguraikan nilai minimum, maksimum, rata-rata dan standar deviasi dari masing-masing variabel.Hasil pengujian statistik deskriptif selama periode pengamatan menunjukkan bahwa :

Variabel likuiditasdiproksikan dengan cash ratio memiliki nilai minimum sebesar 15,34\% yang dimiliki oleh perusahaan PT. Sepatu Bata Tbk (BATA) di tahun 2015. Nilai maksimum likuiditas sebesar 98,31\% yang dimiliki oleh perusahaan PT. Kalbe Farma Tbk (KLBF) di tahun 2012. Nilai meanlikuiditas adalah 54,2635 dan memiliki standar deviasi sebesar 20,96822 menunjukkan variasi yang terdapat di dalam likuiditas.

Variabel profitabilitasdiproksikan dengan ROE memiliki nilai minimum sebesar 10,12\% ditemukan pada perusahaan PT. Pabrik Kertas Tjiwi Kimia Tbk (TKIM) di tahun 2011.Nilai maksimum profitabilitas dimiliki oleh perusahaan PT. Unilever Indonesia Tbk (UNVR) di tahun 2013.Nilai rata-rata ROE adalah 29,3757 dan memiliki standardeviasi sebesar 21,83211. 
Variabel leverage mempunyai nilai minimum sebesar $15,80 \%$ yang dimiliki oleh perusahaan PT. Indocement Tunggal Prakarsa Tbk (INTP) pada tahun 2013. Nilai maksimum 98,45\% dimiliki oleh PT. Indofood Sukses Makmur Tbk (INDF) pada tahun 2014. Rata-rata perbandingan antara laba berseih setelah pajak dengan ekuitas perusahaan sebesar 61,1085 dan memiliki standar deviasi sebesar 26,44745 .

Variabel kebijakan dividen diproksikan dengan dividend payout ratio memiliki nilai minimum sebesar 14,03\% pada perusahaan PT. Pabrik Kertas Tjiwi Kimia Tbk (TKIM) di tahun 2013. Nilai maksimum sebesar 99,89\% dimiliki oleh perusahaan PT. Hanjaya Mandala Sampoerna Tbk (HMSP) pada tahun 2015. Nilai rata-rata DPR adalah 50,8147 dan memiliki standar deviasi 23,02973.

Analisis regresi linier berganda digunakan untuk mengetahui arah dan besarnya pengaruh likuiditas, profitabilitas dan leverage terhadap kebijakan dividen pada perusahaan manufaktur di Bursa Efek Indonesia periode 2011-2015. Hasil regresi linier berganda dalam penelitian ini dapat dilihat pada Tabel 3 berikut.

Tabel 3.

Analisis Regresi Linier Berganda

\begin{tabular}{|c|c|c|c|c|c|c|}
\hline & \multirow[t]{2}{*}{ Model } & \multicolumn{2}{|c|}{ Unstandardized Coefficients } & \multirow{2}{*}{$\begin{array}{c}\text { Standardized } \\
\text { Coefficients } \\
\text { Beta }\end{array}$} & \multirow[t]{2}{*}{$\mathrm{t}$} & \multirow[t]{2}{*}{ Sig. } \\
\hline & & B & Std. Error & & & \\
\hline \multirow[t]{4}{*}{1} & (Constant) & 28.182 & 8.471 & & 3.327 & .001 \\
\hline & Likuiditas & .325 & .101 & .296 & 3.216 & .002 \\
\hline & Profitabilitas & .557 & .091 & .528 & 6.136 & .000 \\
\hline & Leverage & -.186 & .078 & -.213 & -2.376 & .020 \\
\hline
\end{tabular}

Sumber: Data Diolah, 2017.

Berdasarkan analisis data yang telah ditampilkan pada tabel 4.6 maka dapat dibuat persamaan regresi linier berganda sebagai berikut: 


$$
\mathrm{Y}=28,182+0,325 \mathrm{X}_{1}+0,557 \mathrm{X}_{2}-0,186 \mathrm{X}_{3}
$$

Persamaan regresi linier berganda tersebut menunjukkan arah masingmasing variabel bebas terhadap variabel terikatnya, dimana koefisien regresi variabel bebas yang bertanda positif berarti mempunyai pengaruh yang searah terhadap kebijakan dividen dan yang bertanda negatif berarti mempunyai pengaruh yang berlawanan terhadap kebijakan dividen.Persamaan regresi tersebut dapat diuraikan sebagai berikut.

Nilai $\beta_{0}=$ artinya apabila likuiditas, profitabilitas, dan leverage sama dengan nol, maka kebijakan dividen adalah sebesar 28,182 persen. $\beta_{1}=0,325$ artinya bahwa setiap peningkatan 1 persen likuiditas $\left(\mathrm{X}_{1}\right)$ maka kebijakan dividen akan naik sebesar 32,5 persen dengan asumsi variabel lainnya konstan. Koefisien regresi likuiditas bertanda positif menandakan bahwa, likuiditas berpengaruh positif terhadap dividen.

Nilai $\beta_{2}=0,557$ artinya bahwa setiap peningkatan 1 persen profitabilitas $\left(\mathrm{X}_{2}\right)$ maka kebijakan dividen akan naik sebesar 55,7 persen dengan asumsi variabel lainnya konstan.Koefisien regresi profitabilitas bertanda positif menandakan bahwa, profitabilitas berpengaruh positif terhadap kebijakan dividen.

Nilai $\beta_{3}=-0,186$ artinya bahwa setiap peningkatan 1 persen leverage $\left(\mathrm{X}_{3}\right)$ maka kebijakan dividenakan menurun sebesar 18,6 persen dengan asumsi variabel lainnya konstan.Koefisien regresi leverage bertanda negatif menandakan bahwa, leverage berpengaruh negatif terhadap kebijakan dividen.

Tabel 4. Analisis Regresi Linier Berganda

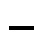




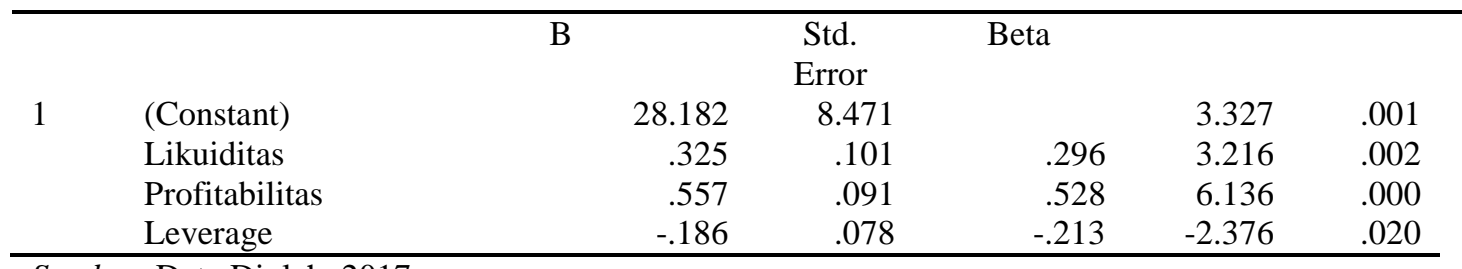

Sumber: Data Diolah, 2017.

Pengujian hasil masing-masing variabel bebas (X) terhadap variabel terikat (Y) dalam penelitian ini menggunakan uji t yang pengujiannya dilakukan dengan uji satu sisi. Penjelasan pengaruh masing-masing variabel bebas (likuiditas, profitabilitas dan leverage), secara parsial terhadap variabel terikat kebijakan dividen dapat dilihat pada Tabel 4 diatas.

Hipotesis pertama dalam penelitian ini meyatakan bahwa likuiditas berpengaruh positif dan signifikan terhadap kebijakan dividen. Berdasarkan Tabel 4 terlihat bahwa besar nilai koefisien regresi likuiditas adalah sebesar 0,325 dengan taraf signifikansi sebesar $0,002<0,05$.Secara parsial dapat disimpulkan bahwa likuiditas berpengaruh positif dan signifikan terhadap kebijakan dividen, dengan demikian hipotesis pertama $\left(\mathrm{H}_{1}\right)$ diterima.

Hipotesis kedua dalam penelitian ini menyatakan bahwa profitabilitas berpengaruh positif dan signifikan terhadap kebijakan dividen. Berdasarkan Tabel 4 terlihat bahwa besar nilai koefisien regresi profitabilitasadalah sebesar 0,557 dengan taraf signifikansi sebesar $0,000<0,05$. Secara parsial dapat disimpulkan bahwa profitabilitas berpengaruh positif dan signifikan terhadap kebijakan dividen,dengan demikian hipotesis kedua $\left(\mathrm{H}_{2}\right)$ diterima.

Hipotesis ketiga dalam penelitian ini menyatakan bahwa leverage berpengaruh negatif dan signifikan terhadap kebijakan dividen. Berdasarkan Tabel 4 terlihat bahwa besar nilai koefisien regresi leverageadalah sebesar -0,186 
dengan taraf signifikansi sebesar $0,020<0,05$. Secara parsial dapat disimpulkan bahwa leverage berpengaruh negatif dan signifikan terhadap kebijakan dividen, dengan demikian hipotesis ketiga $\left(\mathrm{H}_{3}\right)$ diterima.

Tabel 5.

Uji Koefisien Determinasi

\begin{tabular}{llrrr}
\hline Model & R & R Square & $\begin{array}{c}\text { Adjusted R } \\
\text { Square }\end{array}$ & Std. Error of the Estimate \\
1 & .715 (a) & .512 & .491 & 16.42900 \\
\hline
\end{tabular}

Sumber: Data Diolah, 2017.

Nilai Adjusted $\mathrm{R}^{2}$ dalam penelitian ini adalah sebesar 0,491 yang berarti variabel bebas dalam penelitian ini yaitu likuiditas, profitabilitas dan leverage dalam model regresi secara serempak mempengaruhi variabel terikat yaitu kebijakan dividen sebesar 49,1 persen, sedangkan 50,9 persennya dijelaskan oleh faktor-faktor lain diluar variabel bebas yang digunakan dalam penelitian ini.

\section{Pengaruh profitabilitas terhadap kebijakan dividen pada perusahaanmanufaktur di Bursa Efek Indonesia}

Pengaruh profitabilitas pada kebijakan dividen, berdasarkan hasil perhitungan regresi linear berganda yang dirangkum pada Tabel 4.12 dapat diketahui bahwa hasil uji menunjukkan nilai signifikan variabel profitabilitas adalah sebesar 0.000 lebih kecil dari taraf signifikansi 0,05 dan koefisien regresi sebesar 0,557. Hasil penelitian menunjukkan secara parsial profitabilitas berpengaruh positif signifikan terhadap kebijakan dividen.

Perusahaan dengan tingkat return on equity yang tinggimaka akan semakin tinggi pula dividen yang dibayarkan.Tingkat profitabilitas perusahaan manufaktur 
di Bursa Efek Indonesia periode 2011-2015 mengalami fluktuasi setiap tahunnya.Tinggi rendahnya profitabilitas mempengaruhi dividen yang dibagikan.

Perusahaan manufaktur di Bursa Efek Indonesia periode 2011-2015 dengan tingkat profitabilitas yang tinggi mempengaruhi besarnya dividen yang dibagikan.Semakin besar keuntungan yang diperoleh perusahaan, maka akan semakin besar pula kemampuan perusahaan untuk membayar dividen. Pada Tabel 4.4 perusahaan manufaktur dengan tingkat profitabiitas tinggi mempengaruhi dividen yang dibagikan oleh perusahaan rendah. Perusahaan dengan tingkat keuntungan yang tinggi menggunakan laba perusahaan dengan berinvestasi untuk keuntungan perusahaan di masa depan, sehingga dividen yang dibayarkan rendah.

Hasil penelitian ini sejalan dengan penelitian yang telah dilakukan oleh Abdelsalam (2008), Uwuigbe et al. (2012), Juhandi et al. (2013), Al-Nawaiseh (2013), Hardiatmo dan Daljono (2013), Malik et al(2013), Nursalam (2013) dan Estiaji (2014) yang menyatakan bahwa profitabilitas berpengaruh positif dan signifikan terhadap kebijakan dividen.

\section{Pengaruh leverage terhadap kebijakan dividen pada perusahaanmanufaktur di Bursa Efek Indonesia}

Berdasarkan hasil perhitungan yang ditunjukkan pada Tabel 4.12 dapat dilihat bahwa hasil uji menunjukkan nilai signifikan variabel leverage adalah sebesar 0,020 lebih kecil dari taraf signifikansi 0,05 dan koefisien regresi sebesar -0,186. Penelitian ini menemukan bahwa DER berpengaruh negatif dan signifikan terhadap kebijakan dividen.Pengaruh negatif artinya, semakin tinggi utang perusahaan maka dividen yang dibayarkan rendah.Demikian sebaliknya,penggunaan utang yang bertambah dapat meningkatkan kemampuan 
perusahaan dalam membayar dividen selama penggunaan utang menghasilkan tambahan laba.

Perusahaan Manufaktur di Bursa Efek Indonesia Periode 2011-2015 dengan tingkat hutang yang tinggi cenderung akan membagikan dividen yang kecil. Perusahaan dengan rasio utang yang tinggi mempengaruhi rendahnya profit yang diperoleh peusahaan, karena sebagian digunakan untuk membayar bunga pinjaman. Perusahaan dengan beban utang semakin tinggi, maka kemampuan perusahaan untuk membagi dividen akan semakin rendah.

Komitmen perusahaan manufaktur di Bursa Efek Indonesia periode 20112015 untuk melakukan pembayaran dividen secara teratur menyebabkan kemampuan pembayaran dividen tidak dipengaruhi oleh besar kecilnya utang perusahaan bahkan kenaikan hutang dapat menigkatkan kemampuan perusahaan membayar dividen selama penggunaan hutang harus selalu diiringi dengan peningkatan laba perusahaan.

Hasil penelitian ini membuktikan bahwa semakin tinggi DER, perusahaan akan cenderung memberikan dividen yang rendah.Hasil ini sejalan dengan hasil penelitianAl-Kuwari (2009), Abor dan Bokpin (2010), John (2010), Jannati (2012), Sunarya (2013), Rachmad dan Muid (2013), Lopolusi (2013) dan Huda dan Abdullah (2013)yang menyatakan bahwa leverage berpengaruh negatif dan signifikan terhadap kebijakan dividen.

\section{SIMPULAN DAN SARAN}


Simpulan yang dapat diambil berdasarkan hasil penelitian dan pembahasan yang telah diuraikan pada bab sebelumnya adalah sebagai berikut. Likuiditas berpengaruh positif signifikan terhadap kebijakan dividenpada perusahaan manufaktur di Bursa Efek Indonesia selama periode 2011-2015.Profitabilitas berpengaruh positif signifikan terhadap kebijakan dividen pada perusahaan manufaktur di Bursa Efek Indonesia selama periode 2011-2015.Leverage berpengaruh negatif signifikan terhadap kebijakan dividenpada perusahaan manufaktur di Bursa Efek Indonesia selama periode 2011-2015.

Berdasarkan hasil penelitian dan simpulan yang ada, maka saran yang diberikan peneliti adalah sebagai berikut.Bagi perusahaan, pihak manajemen perusahaan perlu mempertimbangkan faktor-faktor likuiditas, profitabilitas dan leverage yang terbukti dalam penelitian ini seignifikan mempengaruhi pembayaran dividen dalam mengusulkan tingkat pembayaran dividen pada saat Rapat Umum Pemegang Saham (RUPS) sehingga dalam pelaksanaannya akan saling menguntungkan antara pihak manajemen dan pihak investor.

Bagi pihak investor yang mengambil keputusan melakukan investasi sebaiknya mempertimbangkan likuiditas, profitabilitas dan leverage perusahaan. Berdasarkan penelitian semakin tinggi tingkat likuiditas dan profitabilitas maka pembagian dividen terhadap investor semakin tinggi pula karena terbukti likuiditas dan profitabilitas berpengaruh positif signifikan terhadap kebijakan dividen pada perusahaan manufaktur periode 2011-2015. Investor juga diharapkan dapat memperhatikan leverage perusahaan, semakin tinggi tingkat utang perusahaan maka pembagian dividen terhadap investor rendah, karena terbukti 
Ni Gusti Ayu Putu Debi Monika, Pengaruh Likuiditas, ...

leverage berpengaruh negatif signifikan pada perusahaan manufaktur periode 2011-2105. Informasi mengenai kondisi perusahaan manufaktur periode 20112015 di Bursa Efek Indonesia diharapkan dapat memberikan gambaran tentang perkembangan perusahaan, yang nantinya akan membantu investor dalam mengambil keputusan investasi.

\section{REFERENSI}

Abdelsalam, Omneya; Ahmed El-Masry dan Sabri Elsegini. 2008. Board composition, ownership structure, and dividends policies in emerging market. Managerial Finance.34(12): pp: 953-964.

Abor, J. And Bokpin, G. A. 2010. Investment Opportunities, Corporate Finance, and Dividend Payout Policy: Evidence From Emerging Markets. Studies in Economics and Finance, 27(3), pp: 180-194.

Adnyana, I Gede. 2014. Pengaruh Likuiditas, Manajemen Aktiva, EPS, dan Ukuran Perusahaan Terhadap Kebijakan Dividen dan Nilai Perusahaan. EJurnal Manajemen Universitas Udayana, 3(12): h: 3707-3724.

Aljannah, Regina Ariesta. 2010. "Analisis Pengaruh Hutang, Profitabilitas, Likuiditas Dan Pertumbuhan Terhadap Dividen (Studi Empiris Di Bursa Efek Indonesia Tahun 2006-2008," Skripsi. Universitas Diponogoro. Semarang.

Al-Kuwari, D. 2009. Determinants of the Dividend Policy in Emerging Stock Exchanges: The Case of GCC Countries. Global Economy \& Finance Journal, 2(2), pp: 371-385

Al-Nawaiseh, Mahmoud. 2013. Dividend Policy and Ownership Structure: An Applied Study on Industrial Companies in Amman Stock Exchange. Journal of Management Research, 5(2): pp: 83-106.

Brigham, Eugene F.\& Houston, Joel F. 2011. Dasar-Dasar Manajemen Keuangan.Edisi Kesebelas. Buku Pertama. Jakarta: Salemba Empat.

Deitiana, Tita. 2013. Pengaruh Current Ratio, Return on Equity dan Total Asset Turn Over Terhadap Devidend Payout Ratio dan Implikasi Pada Harga Saham Perusahaan LQ 45. Jurnal Bisnis dan Akuntansi. 15(1), h: 82-88.

Dewi, Ni Wayan Trisna dan Sedana, Ida Bagus Panji. 2012. Penaruh Struktur Modal, Likuiditas dan Pertumbuhan terhadap Kebijakan Dividen di BEI. Jurnal Akuntansi. 16(3). Bali: Universitas Udayana. 
Dinata, I M. Agus Surya dan I Putu Yadnya.2014. Pengaruh Profitabilitas dan Struktur Kepemilikan terhadap Kebijakan Dividen dan Nilai Perusahaan.EJurnal Manajemen, 3(11): h: 3195-3204.

Elissya, L.K. 2013.Analisis Faktor-faktor yang Mempengaruhi Kebijakan Dividen pada Perusahaan Manufaktur yang Tercatat di BEI pada Periode 20072011.Jurnal Fakultas Ekonomi dan Bisnis. Universitas Lampung.

Estiaji, Ayu Destasiwi. 2014. Pengaruh Insider Ownership, Return on Equity, Free Cash Flow, Firm Size dan Debt to Equity Ratio terhadap Dividend Payout Ratio pada Perusahaan Manufaktur yang Terdaftar di Bursa Efek Indonesia Periode 2010-2013. Skripsi.Fakultas Ekonomi Universitas Negeri Yogyakarta.

Griffin, Carroll H. 2010. Liquidity and Dividend Policy: International Evidence. International Business Research, 3 (3), pp: 03-09.

Gumanti, Tatang Ary. 2013. Kebijakan Dividen Teori, Empiris, dan Implikasi. Jakarta: UPP STIM YKPN.

Hanafi, Mamduh M. 2008. Manajemen Keuangan. Edisi Pertama. Yogyakarta: BPFE.

Hardiatmo, Budi dan Daljono.2013. Analisis Faktor-Faktor yang Mempengaruhi Kebijakan Dividen (Studi Empiris Perusahaan Manufaktur yang listing di Bursa Efek Indonesia Periode 2008-2010).Diponegoro Journal of Accounting, 2(1): h: 1-13.

Horne,James C. Van dan John M Wachowicz, Jr. 2012. Prinsip-prinsip Manajemen Keuangan.Edisi 12 Buku 2. Jakarta: Salemba Empat.

Huda, Nusrat dan Mohammad Nayeem Abdullah. 2014. "Relationship between Ownership Structure and Dividend Policy: Empirical Evidence from 78 Chittagong Stock Exchange". World Review of Business Research, 4(3), pp: 14-34.

Husnan dan Pudjiastuti. 2012. Dasar-Dasar Manajemen Keuangan. Edisi 6.Yogyakarta : UPP STIM YKPN.

Imran, Kashif. 2011. Determinants of Dividend Payout Policy: A Case of Pakistan Engineering Sector. The Romanian Economic Journal, 14 (41), pp: 47-60.

Islam, Talat; Muhammad Aamir; Ashfaq Ahmad dan Muhammad Saeed. 2012. Determinants and Motivators Of Dividend Policy: A Study Of Cement Industry Of Pakistan. Mediterranean Journal Of Social Sciences. 3(2), pp: 103-108.

Jannati, Attina, 2012. "Pengaruh Profitabilitas, Leverage, dan Growth terhadap Kebijakan Dividen", Jurnal Universitas Siliwangi.1(1). 
John, S. Franklin and K. Muthusamy. 2010. Leverage, Growth, and Profitability as Determinants of Dividend Payout Ratio - Evidence from Indian Paper Industry. Journal of Business Management.26-30.

Juhandi, Nendi, Made Sudarma, Siti Aisjah, dan Rofiaty, 2013, "The Effect of Internal Factors and Stock Ownership Structure on Dividend Policy on Company's Value", International Journal of Businesss and Management Invention, 2(11), pp: 6-18.

Karami, Lalu Candra. 2011. The Influence of Leverage and Liquidity on Dividend Policy(Empirical Study on Listed Companies in Indonesia Stock Exchange of LQ45in 2008-2010). Minor Thesis.

Kasmir. 2012. Analisis Laporan Keuangan: Jakarta : PT Raja Grafindo Persada.

Keown, Arthur J., David F. Scott, Jr., John D. Martin, J. William Petty. (2010). Manajemen Keuangan: Prinsip dan Penerapan Jilid 2 (Edisi Kesepuluh). Jakarta, PT. Indeks.

Khoury, R.E., dan Maladjian, C. (2014). Determinants of the Dividend Policy: An Empirical Study on the Lebanese Listed Banks. International Journal of Economics and Finance.6(4).

Kuwari, A.D. (2010). To Pay or Not To Pay Using Emerging Panel Data to Indentifity Factors Influencing Corporate Dividend Payout Decision.International ResearchJournal Of Finance and Economics, 4(2), pp: 1450- 2887.

Lopolusi, Ita. (2013).“Analisis Faktor-faktor yang mempengaruhi Kebijakan Deviden Sektor Manufaktur yang Terdaftar di PT Bursa Efek Indonesia periode 2007-2011”.Jurnal Ilmiah Mahasiswa Universitas Surabaya, 2(1): h: $1-18$.

Maladjian, Christopher dan El Khoury, Rim. 2014. Determinants of the Dividend Policy :An Empirical Study on the Lebanese Listed Bank. International Journal of Economics and Finance, 6(4), pp: 240-256.

Malik, Fakhra; Sajid Gul; Muhammad Tauseef Khan; Shafiq Ur Rehman dan Madiha Khan. 2013. "Factors Influencing Corporate Dividend Payout Decisions Of Financial and Non-Financial Firms". Research Journal Of Finance and Accounting, 4(1): pp: 35-46.

Mehta, Anupam. 2012. Empirical Analysis of Determinants of Dividend Policy Evidence from the UAE Companies. Global Review of Accounting and Finance, 3 (1), pp: 18-31.

Munawir. 2010. Analisis Laporan Keuangan. Edisi 4. Yogyakarta: Liberty. 
Novatiani, R Ait dan Novi Oktaviani. 2012. Pengaruh Profitabilitas, Likuiditas, Leverage, dan Ukuran Perusahaan Terhadap Kebijakan dividen Pada Perusahaan Manufaktur Di Sektor Industri Barang Konsumsi Yang Terdaftar Di Bursa Efek Indonesia. Jurnal Skripsi. h: 1-24.

Nugroho D, R Fajar. 2010. Analisis Pengaruh Return On Equity, Insider Ownership, Investment Opportunity Set, Firm Size, Cash Flow, dan Debt Ratio Terhadap Dividend Payout Ratio. Skripsi.Jurusan Manajemen Fakultas Ekonomi Universitas Diponegoro, Semarang.

Nursalam, Machfud. 2013. Pengaruh Arus Kas Bersih, Rentabilitas Modal Sendiri dan Likuiditas Terhadap Dividen Payout Ratio Pada Perusahaan Manufaktur yang Terdaftar di Bursa Efek Indonesia (BEI). Skripsi.Fakultas Ekonomi Universitas Negeri Padang.

Rachmad, Anggie Noor dan Muid, 2013, "Pengaruh Struktur Kepemilikan, Leverage, dan Return on Assets (ROA) Terhadap Kebijakan Dividen", Diponogoro Journal of Accounting, 2(3): h: 1-11.

Rahayuningtyas, Septi. 2014. Pengaruh Rasio-Rasio Keuangan Terhadap Dividend Payout Ratio (DPR) (Studi Pada Perusahaan yang Listing Di BEI Tahun 2009 - 2011). Jurnal Administrasi Bisnis (JAB),7(2).

Rehman, Abdul dan Haruto Takumi. 2012. Determinants of Dividend Payout Ratio : Evidence form Karachi Stock Exchange (KSE). Interdisciplinary Journal of Contemporary Research in Business.20-27.

Sartika, Sari Eka. 2014, "Pengaruh Ukuran Perusahaan, Likuiditas, Profitabilitas, Pertumbuhan Perusahaan dan Kepemilikan Institusional terhadap Kebijakan Dividend Payout Ratio".Skripsi. Universitas Dahasen, Bengkulu.

Sartono, Agus. 2010. Manajemen Keuangan Teori dan Aplikasi.Edisi 4. Yogyakarta: BPFE.

Sudana, I Made. 2011. Manajemen Keuangan Perusahaan Teori \& Praktek. Jakarta: Penerbit Erlangga.

Sunarya, Devi, Hoe. 2013. Pengaruh Kebijakan Utang, Profitabilias dan Likuiditas Terhadap Kebijakan Deviden dengan Size Sebagai Variable Moderasi Pada Sektor Manufaktur Periode 2008-2011. Jurnal Ilmiah Mahasiswa Universitas Surabaya, 2(1): h: 3-19.

Suprasanda, Viky. 2011. Faktor-faktor yang Mempengaruhi Kebijakan Pembayaran Dividen pada Perusahaan Manufaktur di Bursa Efek Indonesia. Skripsi. Malang: Universitas Brawijaya Malang. 
Ni Gusti Ayu Putu Debi Monika, Pengaruh Likuiditas, ...

Thanatawee, Yordying. (2013). Ownership Structure and Dividend Policy: Evidence from Thailand. International Journal of Economics and Finance, 5(1), pp: 1923-4023.

Wiagustini, Ni luh Putu. 2010. Dasar-Dasar Manajemen Keuangan. Denpasar: Udayana University Press.

Wicaksana, I Gede Ananditha. 2012. Pengaruh Cash Ratio, Debt to Equity Ratio, dan Return on Asset terhadap Kebijakan Dividen pada Perusahaan Manufaktur di BEI. Tesis Universitas Udayana. Denpasar. 